towards morning moderated, and brilliant flashes of lightning were seen to the east ward."

Lloyd's, London, E.C., January II

CHARLES WEST

The Admiralty Manual on Terrestrial Magnetism

IN a recent number of NATURE you mention that the new edition of the Admiralty Manual on Terrestrial Magnetism is being edited by me. It gives me great pleasure to be able to inform those interested in this work that I have obtained the advice and assistance of Capt. Creak and $\mathrm{Mr}$. Whipple as to the changes required in the description of the ship- and landobservations respectively. From the guidance of such able specialists I feel that the work will have a value that it could never have had from my unaided exertions.

Trinity College, Dublin, January 6

GEO. Fras. Fitzgerald

\section{Anchor Frosts}

ON the night of Friday, January 8, there was an anchor frost in the Cherwell such as has not been known for twenty years, according to people who have lived at a mill on the river (Clifton Mill, near Aynho Station) for that period. In a mild form the phenomenon is fairly frequent there. The most marked effects are seen in comparatively still water.

Thus, in the mill-pond, where the current is stopped by the mill during the night, the whole stream becomes semi-viscous. Roots beneath the water, the brickwork at the sides of the millpond, \&c., are seen to be coated with ice beneath the water as far down as can be seen, and between this ice and the surface ice-crystals form, not in a sheet or block, but interlaced loosely, like snow crystals in a drift. The mass thus formed blocks the channel, and it is said that water coming upon it from above will rise in level and flow over it, as over a solid obstruction. This I have not seen myself.

When the mill is started, at first the water will hardly flow past the wheel ; but at length the crystals are forced to the surface, where they remain in floating masses, under which the water flows as usual.

The surface is not covered with a sheet of ice in these frosts.

In a broad, shallow ditch at right angles to the river, where the water i; comparatively still, similar effects could be seen : the pebbles at the bottom coated with ice and the water filled with loose crystals. One consequence of the bottom ice forming on this occasion was that the floodgates were frozen down on the Friday evening, so that they could not be drawn up as usual, and the river overflowed during the night. In the morning, when they were at last raised, the water would hardly flow through, as already mentioned in the case of the waterwheel.

T. HANDS

Clifton Mill, near Aynho Station

\section{Curious Phenomenon in Cephalonia}

I BEG leave to forward to you an extract from a letter which I have recently received from a friend a d former pupil who is at present an officer on board one of Her Majesty's ships in the Mediterranean. I have never seen any reference to the phenomenon which he describes. If you can insert the extract, perhaps it may evoke further information with regard to it. I would not forward the statement unless I had every confidence in the writer, so that I do not think he would be likely to be easily deceived or mistaken in his observations. $\mathrm{He}$ is a gentleman who tosk an excellent position in the Cambridge Mathematical Tripos.

Barham, January 7

E. LEDGER

"By the way, at Cephalonia there is a very remarkable phenomenon. The sea runs into the land in a strong stream, turning a water-wheel on the way, and disappears in the earth about a hundred yards from the entrance. Can you explain this? I believe no one has yet done so. No part of the island is below the level of the sea, nor is there any salt lake or spring in the island. I imagine this water must be converted into steam, which comes out either at Naples or Stromboli."

\section{SIR F. F. O. EVANS}

CAPTAIN SIR FREDERICK J. O. EVANS, R.N., K.C.B , F.R.S., late Hydrographer of the Admiralty, died at his residence, $2 \mathrm{I}$, Dawson Place, on December 20, 1885 , in his seventy-first year.
This eminently scientific officer entered the Royal Navy in the year 1828, and served in H.M. ships Rose and Whinchester, on the North American station, until I 833, when he was transferred to H.M. surveying-vessel Thunder, Commander Richard Owen, and was employed until 1836 in surveying operations in various parts of the West Indies.

It was in this ship, and under the guidance of her able Captain, that he imbibed those scientific tastes which formed his character later in life, and laid the foundation of a career of usefulness, uninterrupted to its close, and which has perhaps rarely found a parallel in the naval profession.

Mr. Evans subsequently served in the Caledoniat, the flag-ship in the Mediterranean, the Asia, the Rapid, the Rolla, the Dido, and Wolverene, of which two latter ships he was acting master. He was confirmed in that rank in I $84 \mathrm{I}$, and was then appointed to H.M.S. Fly, Capt. F. P. Blackwood, fitting for special exploring and surveying service in Australia and New Guinea, where he was continuously employed until $\mathrm{I} 846$. He took a very leading part in the examination of the Coral Sea, the Barrier Reefs of Australia, Torres Strait, and the neighbouring shores of New Guinea, regions then comparatively unknown. After a short period of surveying service on the home coasts, Evans was appointed to the Acheron, under the late Admiral Stokes, and was engaged until $185 \mathrm{I}$ in exploring and surveying the coasts of the then young colony of New Zealand; in both these important enterprises he took a very conspicuous part, and gained for himself the reputation of a skilful and scientific surveying officer, second to none in the profession.

During the Russ ian war Evans was employed in the Baltic on special reconnoitring service, and was attached to various ships of the fleet, ta'ing an active part in the operations against Bomarsund and among the Aland Isles, for which he was mentioned in gazetted despatches.

It may be truly said-that for many years of his life Evans was a zealous contributor to magnetic science. He had already begun to make observations of the three magnetic elements whilst employed on hydrographic work in H.M. ships Fly and Acheron in the Australian Colonies and New Zealand, between the years $1842-1851$; but it was not until I 855 , when he became Superintendent of the Compass Department of the Royal Navy that he was able to devote himself entirely to the magnetism of iron ships, a subject which was then growing yearly in importance, from the increasing amount of iron used in fitting as well as construction even before iron plating had brought about an actual crisis.

Sagaciously fore-eeing the important part the science of magnetism was destined to play in the Navy, then being revolutionised by the change from wood to iron, he devoted his whole energies to the study of the subject until he had made himself completely master of it.

In 1865 Capt. Evans was appointed Chief Assistant to the Hydrographer, retaining his position as head of the magnetic department; this post he continued to hold until the early part of 1874 , when a vacancy occurring in the Hydrographership of the Admiralty he was selected to fill it, and continued to do so with equal ability and conscientiousness until within a little more than a year of his death.

From the time of his first appointment in 1855 as Chief of the Admiralty Compass Department until his death Capt. Evans (in happy co-operation during a great part of the time with that great mathematical genius Archibald Smith) devoted himself heart and soul to the solution of what was really a question of life and death to the British Navy, and indeed to seafaring people all over the world. The question was whether it was possible so to deal with the disturbing element of iron, then entering largely into the construction of ships of all kinds, as to prevent the time-honoured compass from becoming a useless toy, or 
even a misleading guide. Now that the difficulty has been grappled with and conquered, we have half learned to forget the magnitude of the peril. But for the scientific and practical progress due to the labours of Capt. Evans and Archibald Smith we might almost with advantage have thrown all our compasses overboard. The attraction due partly to the inherent and partly to the induced magnetism of iron ships, and especially of plated ships, was so violent as to induce in some vessels, in certain positions, errors of two, three, or four points of compass indication. Something had been done to explain the causes of the mischief and to suggest palliatives. Famous old Flinders, at the beginning of the century, had spelt out the mystery so far as it was disclosed by the wooden ships of his time, but he had to deal with com. paratively minute errors due to induction alone, and was never brought face to face with the stupendous difficulty which iron shipbuilding and iron ship-plating, afterwards created. The late Astronomer-Royal had done good and sound work in the earlier days of iron, but much more was needed to overcome the serious trouble which the newer types of mercantile and still more of naval vessels threatened to bring upon us.

It was at this critical epoch that Capt. Evans and Archibald Smith began to work together. Years of experimental labour and mathematical research went to the production of the "Admiralty Manual on Deviations of the Compass"-a book perhaps as perfect in its kind as a book could be. It is hard to do justice to the elegance of the mathematical handling, and, above all, to the happiness of the graphic methods which are found in the Manual, without seeming to indulge in extravagant laudation. An enthusiast in such matters once pronounced it a piece of lovely work, and one need not be an enthusiast to appreciate all that the epithet was meant to carry. Capt. Evans would have been the last to deny that the larger part of the purely theoretical investigation was due to his brilliant fellow-worker. Indeed his modesty often prompted him to claim less than his fair share of the credit due to both. The subject was one which called for the combination of practical sagacity and experience with refined scientific method-and if Archibald Smith was the stronger on the one side, Capt. Evans was his master on the other; nor was either of them without large powers, even in the special department of their joint labour in which he owned the supremacy of his friend. It was an undertaking which called for the united effort of just two such men as were fortunately brought together to do it, and the result has been a triumph to England and a blessing to the world which will preserve the memories of its authors as long as the ocean remains the highway of Englishmen and of the world.

The death of his old colleague did not abate the zeal of Capt. Evans, and few years passed since that time without some notable addition from the hands of the Hydrographer to our existing stock of experimental knowledge and scientific theory upon the subject which he had made his own. Much of his work will be found in the Philosophical Transactions of the Royal Society, and in 1870 he published an elementary manual supplementary to the Manual ; both these works have been freely translated on the Continent, and are the acknowledged text-books in our own and foreign Navies to the present time.

The various steps of Evans's work may thus be stated :-

In 1858 a Chart of Curves of Equal Magnetic Declination, compiled by him for that epoch, was published by the Admiralty. This chart appeared most opportunely, for, with compass errors growing in amount and comflexity, the mariner was by means of it enabled to ascertain in any part of the navigable world how far his compass deviated from the magnetic north.

In 1859 he read a paper on the magnetism of iron ships at the Royal United Service Institution. This was valuable résumé of all that had been hitherto done in order to obtain a knowledge of the magnetism of iron ships and the treatment of their compasses. He also communicated some results of Archibald Smith's method of analysis as applied to the errors of the compass found in H.M. ships.

Evans's next paper consisted of a Report to the Hydrographer of the Admiralty on Compass Deviations in the Royal Navy. It treated of the magnetic character of the various iron ships in the Navy, and also of the Great Eastern steamship. The results of this paper were (I) to show the best direction for building an iron ship; (2) the best position for placing her compass; (3) the various sources of error affecting a compass under favourable conditions. This report was communicated to the Royal Society, and published in their Transactions in 1860.

In 186 I he read a paper of similar import before the Institute of Naval Architects.

Reference has already been made to his work on the Great Eastern, and an important result of it was the experimental investigation which he was led to make as to the cause of the abnormal errors of the compasses in that vessel, proceeding from the application of Airy's system of magnet and soft-iron correctors when long singlecompass needles are used.

With Evans principally as an experimentalist and Archibald Smith as the mathematician, a valuable paper on the proper length and arrangement of the needles on a compass card, together with exact information as to the proper arrangement of magnet and soft-iron correctors with respect to it, was presented to the Royal Society in i $86 \mathrm{r}$, being the result of the joint work of those ardent investigators into the compass question in iron ships.

Commencing with this latter paper, we find Evans and Smith as we have said above, generally working together, and under their joint editorship there appeared in 1862 the first edition of the "Admiralty Manual for Deviations of the Compass." The introduction, however, of armourplated ships soon rendered a new edition necessary, and in 1863 it was published. This work was again revised in 1869 , and became the text-book of the world on the important question of the deviations of the compass in iron ships of whatever form, being translated into all the principal European languages.

In $186 ;$ Evans and Smith produced another important paper on the "Magnetic Character of the Armourplated Ships of the Royal Navy," which was published in the Phil. Trans. Roy. Soc. The noveliv of the form of ships thus discussed as regards their mignetic character caused the results to be of more than usual interest, and showed with what degree of confidence compasses might be placed in positions where both helmsman and officer might have armour protection.

The practicability of determining the magnetic coefficients without swinging, and also of ascertaining the heating error without inclining the ship, was also demonstrated, and has since been largely adopted in the Royal Navy.

In 1866 proposals were made by Mr. Evan Hopkins, C.E., to depolarise the iron hulls of ships by means of electro-magnets, and he was allowed by the Admiralty to experiment on the Northumberland, an armour-plated ship lying in the Victoria Docks. With the increasing difficulty of finding suitable positions for the compass, the prospect of being able to depolarise an iron ship was very attractive. In an able paper, however, read before the Royal Society in 1868, Evans showed that, so far from the hull of the Northumberland being depolarised, a portion of it was only temporarily, and therefore dangerously, polarised, and afterwards returned to its normal condition, thus preventing similar experiments being tried with other ships of the Navy.

It was only natural that a joint editor of the "Admir- 
alty Manual for Deviations of the Compass," who knew the difficulties of that work for his fellow-seamen, should wish to present the subject, on which he had worked so long, in an elementary form more suitable to their everyday requirements. Evans therefore, in 1870 , published his " Elementary Manual for Deviations of the Compass," a work which has been very well received by the nautica world, and has been translated into various European languages.

With the exception of some papers read at certain meetings of the British Association, and two lectures read at the Royal United Service Institution in 1865 and 1872 , Evans subsequently relaxed his personal investigations into the magnetism of iron ships, and turned more to terrestrial magnetism.

Thus, in 1872, he contributed a paper to the Royal Society, on the magnetic declination in the British Islands, and compiled the magnetical instructions for the voyage of H.M.S. Challenger, being again assisted in this, and for the last time, by his old fellow-labourer, Archibald Smith.

Lastly, in 1878, Evans read an able and instructive lecture, on the magnetism of the earth, before the Geographical Society, showing the distribution and direction of the earth's magnetic force and the changes in its elements as then known.

Capt. Evans was elected a Fellow of the Royal Society in I862. He sat for many years on its Council, and was more than once a Vice-President. He was also a Fellow of the Royal Astronomical and Geographical Societies; he served for many years as member of the Meteorological Committee of the Royal Society, and on the change in the constitution of that body became a member of its Council.

In recognition of his public services the Companionship of the Bath was conferred upon him in 1873 , and in I88I he was advanced to the Commandership of the same order.

Sir Frederick Evans's last public service after his retirement from the Admiralty in 1884 was as the British Delegate at the Congress of Washington for the establishment of a prime meridian and questions kindred to it.

\section{ZOHN MORRIS}

PROFESSOR JOHN MORRIS died on Thursday, January 7 , having been laid aside by illness for several months. Born at Homerton in 1810 , he spent almost the whole of his life in or near London. For many years a pharmaceutical chemist at Kensington, he passed all his spare time in exploring the neighbourhood of the metropolis and in collecting from field and book the great store of geological knowledge which was one of his especial characteristics. But science claimed more and more of his time, and at last he abandoned business entirely. In 1855 he was appointed Professor of Geology at University College, London, which post he held till 1877 , when he was succeeded by Prof. Bonney. In $\mathrm{I} 878$ the honorary degree of $\mathrm{MA}$. was conferred upon him by the University of Cambridge.

Morris was elected a Fellow of the Geological Society in 1845 , and, whilst in health, was a constant attendant at its meetings. He received the first Lyell Medal in 1876 , and has four times received the Wollaston Donation Fund. In the Geologists' Association he has been an earnest worker, having been twice its President, and always one of the foremost leaders at its excursions.

The earliest publication by Prof. Morris was "Observations on the Strata near Woolwich," in the Magazine of Natural History for 1835. Most of his own descriptive papeis refer to the south-east of England and in the Oolitic districts, but in association with others he has done important wor's elsewhere. His paper with Murchison,
"On the Palæozoic and their Associated Rocks of the Thüringerwald and the Harz," read before the Geological Society in 1855 , is still one of the best accounts of those districts in the English language. He was joint-author with Dr. Lycett of an important monograph for the Palæontographical Society on the Oolitic Mollusca.

Considering the enormous amount of information stored in Morris's mind, one is surprised that comparatively so little original work came from his pen, and especially that so few species of fossils except those of the Great Oolite bear his name as their author. For this, however, we may perhaps be thankful ; he may have been equally well employed in reducing the number of those already in use. This he did to good purpose in his "Catalogue of British Fossils," the first edition of which was published in 1843 , the second in 1854 . From that date onwards he was engaged in collecting materials for a third edition, which unfortunately he did not complete. Every working geologist and palæontologist has made constant use of this book, and those who have used it most best know the vast amount of labour which its preparation entailed. It is not a mere list, compiled from various authors; but nearly every species has been critically examined and the synonymy carefuily traced.

Fond of conversation, a ready and pleasing public speaker, Morris was always glad to impart his knowledge to others. This knowledge was varied and exact; minerals, rocks, and fossils were equally familiar to him, and he was well read in the wider questions of physical geology.

He was held in high regard by all who knew him ; and those who gathered around his grave at Kensal Green came to pay the tribute of personal friendship not less than that of admiration for scientific worth.

\section{DISTRIBUTION OF DRIVING-POWER IN}

\section{LABORATORIES}

$A$ NOVEL arrangement has been adopted at the Physiological Laboratory at Cambridge, and at the Owens College, Manchester, for driving instruments in various rooms by means of a central motor. At the Brown Institution shafting has been used for the same purpose. This method is commonly used for driving machines which require a good deal of power, but it is not suitable for laboratories where the power is often required in many rooms, on different floors and some distance apart, thus causing great complication in the fittings. Again, when shafting is used, the instrument to be driven must be placed opposite a pulley on the shaft ; in the arrangement about to be described, the instrument may be moved to any part of the tables, and the tables can be fixed in any part of the rooms.

We will now describe in detail the arrangement as applied in the Laboratory at Cambridge. The motor is an Otto gas-engine. It was found most convenient to place it in the cellar.

In Fig. I a pulley, B, fixed to a short length of shafting, is driven by a cord from the fly-wheel of the gas-engine, shown at A. The small pulleys at $\mathrm{C}$ are necessary to guide the cord in the required direction. This direction is vertical, hence no sag can compensate for changes of length due to stretching and the varying moisture of the atmosphere. The following arrangement was therefore adopted. Two grooves are turned in the pulley $\mathrm{B}$, over which the cord passes twice, having between the first and second time passed under a pulley which supports a weight, $w$. Thus, the only effect of a change of length in the cord is to raise or lower the weight.

The short length of shafting driven in this manner by the pulley $\mathrm{B}$ is used to distribute the power to various rooms. A cord runs to each room, and forms a separate system, which can be stopped or started independently. This is done in the following manner. Fig. 2 shows a 